\title{
Variability of pikeperch Sander lucioperca (L. 1758) cohorts in early life history
}

\author{
Petr Blabolil*, Martin Čech, Tomáš Jůza and Jiří Peterka \\ Biology Centre of the Czech Academy of Sciences, Institute of Hydrobiology, Na Sádkách 702/7, České Budějovice 370 05, \\ Czech Republic
}

Received: 2 August 2019 / Accepted: 28 September 2019

\begin{abstract}
Year to year fluctuations in 0+ fish cohort strength are a common phenomenon. Many factors can affect cohort strength during the fish's early life period. In this study, development of a $0+$ pikeperch Sander lucioperca cohort in the pelagic zone was studied by trawling for 50 days from first larvae hatching, in two consecutive years. In 2007, an abundant $S$. lucioperca cohort collapsed suddenly soon after hatching. After the incident, slow-growing S. lucioperca prevailed in the catch. In 2008, the catch gradually increased during the whole study period because of prolonged hatching. Environmental factors differed mainly in a slower temperature increase, higher water level and higher zooplankton abundance in 2008 compared to 2007. Our study revealed that a strong $0+S$. lucioperca cohort at the time of hatching might not result in a strong $S$. lucioperca cohort in general.
\end{abstract}

Keywords: Growth / recruitment / temperature / water level / zooplankton

Résumé - Variabilité des cohortes de sandre Sander lucioperca (L. 1758) au début du cycle biologique. Les fluctuations d'une année à l'autre de la force des cohortes de poissons $0+$ sont un phénomène courant. De nombreux facteurs peuvent influer sur la force de la cohorte au début de la vie du poisson. Dans cette étude, le développement d'une cohorte 0+ de sandres Sander lucioperca dans la zone pélagique a été étudié par chalutage pendant 50 jours à partir de l'éclosion des premières larves, pendant deux années consécutives. En 2007, une cohorte abondante de S. lucioperca s'est effondrée soudainement peu après son éclosion. Après l'incident, S. lucioperca à croissance lente a prévalu dans les prises. En 2008, les prises ont augmenté graduellement pendant toute la période d'étude en raison de l'éclosion prolongée. Les facteurs environnementaux différaient principalement par une augmentation plus lente de la température, un niveau d'eau plus élevé et une plus grande abondance du zooplancton en 2008 par rapport à 2007. Notre étude a révélé qu'une forte cohorte de $S$. lucioperca $0+$ au moment de l'éclosion pourrait ne pas donner une forte cohorte de S. lucioperca.

Mots-clés : Croissance / recrutement / température / niveau d'eau / zooplancton

\section{Introduction}

The assessment of population recruitment is crucial for fisheries management to choose an optimal strategy to exploit and maintain natural resources (Jakobsen et al., 2009). Many factors can determine the cohort strength of $0+$ fishes and the importance of these can be dependent on the ontogenetic phase (Eklöv and Persson, 1995; Garvey and Stein, 1998; Hoxmeier et al., 2006; Blabolil et al., 2016). Based on early information on cohort development, fisheries managers can conduct effective actions (e.g. stocking, parental stock support,

\footnotetext{
*Corresponding author: blabolil.petr@seznam.cz
}

spawning and nursery habitat adjustment) to support the target populations (Cowx, 1994).

Fish monitoring in temperate waters is usually conducted in the summer (CEN, 2005; Jůza et al., 2015). At this time, all fishes hatched in the spring are several months old, large enough for easy species identification, and occur in their preferred habitats (Jůza et al., 2015). During early life, many fish species disperse in the pelagic zone where they can be monitored by hydroacoustics and netting (Čech et al., 2005). Non-invasive hydroacustics have a great potential in sampling large water volumes, but species determination is difficult or impossible (CEN, 2014). Quantitative monitoring in the pelagic zone utilising fixed-framed trawls was recently developed to obtain reliable data about $0+$ fish cohorts 
(Jůza and Kubečka, 2007; Jůza et al., 2010). Despite data collection being robust there is considerable variation in estimates of fish abundance (Jůza et al., 2014). Measuring fish length is a common tool to determine growth. To follow cohort development precise ageing is necessary (Ralston and Williams, 1988; Campana, 2001).

In the early larval phase, fishes are highly sensitive to environmental factors (Bone and Moore, 2008). Critical bottlenecks in cohort development can be either of short duration or long-lasting and can deplete fish energetic reserves (Moberg and Mench, 2000). The first important period determining cohort strength is spawning which can be affected by external stimuli such as photoperiod, temperature and availability of appropriate substrata (Balon, 1975; Morgan, 2008). After spawning, hatching and larval development are temperature dependent (Čech et al., 2012). At high temperatures, larvae can hatch earlier, however, a longer time at the egg stage in colder conditions can improve fish development (Wood and McDonald, 1997). The first bottleneck after hatching is switching to exogenous feeding, when adequate food in type and quantity have to be present (Rao, 2003). At high temperatures, fishes have a higher metabolic rate compared to cold conditions and fish starvation is more likely due to high demands on the available food (Pepin, 1991).

In this study, pikeperch Sander lucioperca (L. 1758) was used as a model species. Sander lucioperca is a commercially valuable and a game fish, native to eastern Europe and western Asia and introduced to other European, Asian and north African countries (Specziár and Turcsányi, 2017; FAO, 2018). In natural water bodies, S. lucioperca is a top-predator and therefore it is used in many biomanipulative projects to reduce zooplanktivorous species and increase water quality (Wysujack et al., 2002; Blabolil et al., 2016). At most localities, $S$. lucioperca spawns in spring when the temperature increases to $8^{\circ} \mathrm{C}$. Males create nests as depressions in the bottom substrata that they clean from sediments often containing vegetation. After the eggs are spawned, they protect them until the larvae hatch (Lappalainen et al., 2003). The larvae move into the pelagic zone and in late summer large individuals migrate into the littoral zone (Frankiewicz et al., 1996; Specziár, 2005).

The aim of this study was to monitor the development of $0+S$. lucioperca cohorts from hatching for $c$. 50 days in two consecutive years using quantitative trawling in the lacustrine part of the Rímov Reservoir. In particular, we asked the following questions: Does the whole $S$. lucioperca cohort appear at the same time in the pelagic zone? Do the larvae and juveniles grow continuously during the study period? Is $0+S$. lucioperca growth the same in different years?

\section{Materials and methods}

\subsection{Study site}

The study was conducted in the Rímov Reservoir (Fig. 1). The reservoir (maximum depth $45 \mathrm{~m}$, average depth $16 \mathrm{~m}$, surface area 210 ha, volume $33.1 \times 10^{6} \mathrm{~m}^{3}$ ) was built on the Malše River in 1978 for drinking water storage, flood control and hydroelectric power generation. The river is the main inflow with the long-term annual average water flow varying from 2.8 to $7.0 \mathrm{~m}^{3} \mathrm{~s}^{-1}$. The reservoir is dimictic with welldeveloped thermal stratification during the summer. A a)
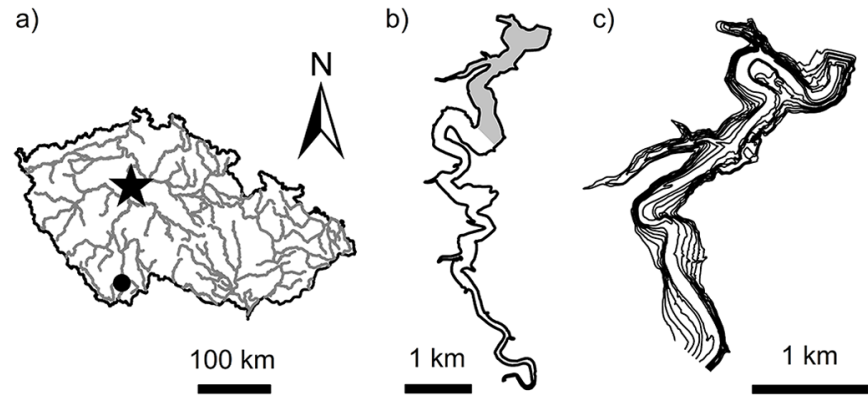

Fig. 1. (a) Location of the Ř́mov Reservoir (black circle) and Prague (star symbol) within the Czech Republic. (b) Map of the Rímov Reservoir with the lacustrine part (grey area) and (c) bathymetric map of the area with lines in $5 \mathrm{~m}$ intervals.

longitudinal gradient of productivity is developed and total phosphorus and chlorophyll- $a$ concentrations are highest at the tributary and decrease downstream towards the dam (Sed'a and Devetter, 2000). The largest part of the reservoir in terms of volume $(56 \%)$ and significant area $(32 \%)$ is the mesotrophic lacustrine part (Fig. 1b), which has homogenous conditions. In the reservoir a long-term biomanipulation project has been conducted and predatory fishes have been propagated since 1985 (Ríha et al., 2009). Despite the presence of a viable S. lucioperca population, natural recruitment is highly variable between years (Blabolil et al., 2016).

\subsection{Fish sampling and processing}

The $0+$ fishes were collected on 1, 11, 21, 31 May and 12 June in 2007 and 24 April, 1, 5, 26 May and 5, 11, June in 2008. Fish sampling was done using a fixed-frame trawl with a mouth opening of $0.5 \times 2 \mathrm{~m}$ in April and early May followed by $2 \times 2 \mathrm{~m}$ opening in late May and July, a mesh size of $1 \times 1.35 \mathrm{~mm}$, with a collecting bucket at the end of the net (Jůza et al., 2010). The trawl was towed $100 \mathrm{~m}$ behind a boat at a speed of $1 \mathrm{~m} \mathrm{~s}^{-1}$. Trawling was performed in the pelagic (0-2 $\mathrm{m}$ depth) at a maximum distance of $1.5 \mathrm{~km}$ from the dam before the meandering part of the reservoir (Fig. 1b). The trawling was conducted at night with the exception of 12 June in 2007 and 26 May in 2008 when the sampling was done during the day. The trawl trajectory was measured by a GPS device and the sampled volume was calculated. A random subsample of $0+S$. lucioperca was immediately taken from the catch and frozen for laboratory processing, the other fishes were anaesthetized, and subsequently preserved in $4 \%$ formaldehyde solution.

In the laboratory, defrosted $S$. lucioperca were measured for standard length $\left(L_{\mathrm{S}}\right)$ with precision of $0.5 \mathrm{~mm}$, sagittae otoliths for age determination were extracted, cleaned from any attached tissues and mounted on microscope slides using thermoplastic glue (Crystalbond 509 clear). The otoliths were viewed using an Olympus AX70 microscope $(\times 200-600$ magnification). When necessary to improve clarity, the otoliths were ground with a sandpaper of 400 and 600 grit (Blabolil et al., 2018). The formaldehyde-fixed fishes were identified to species and $S$. lucioperca were counted and measured as for the defrosted sample. 


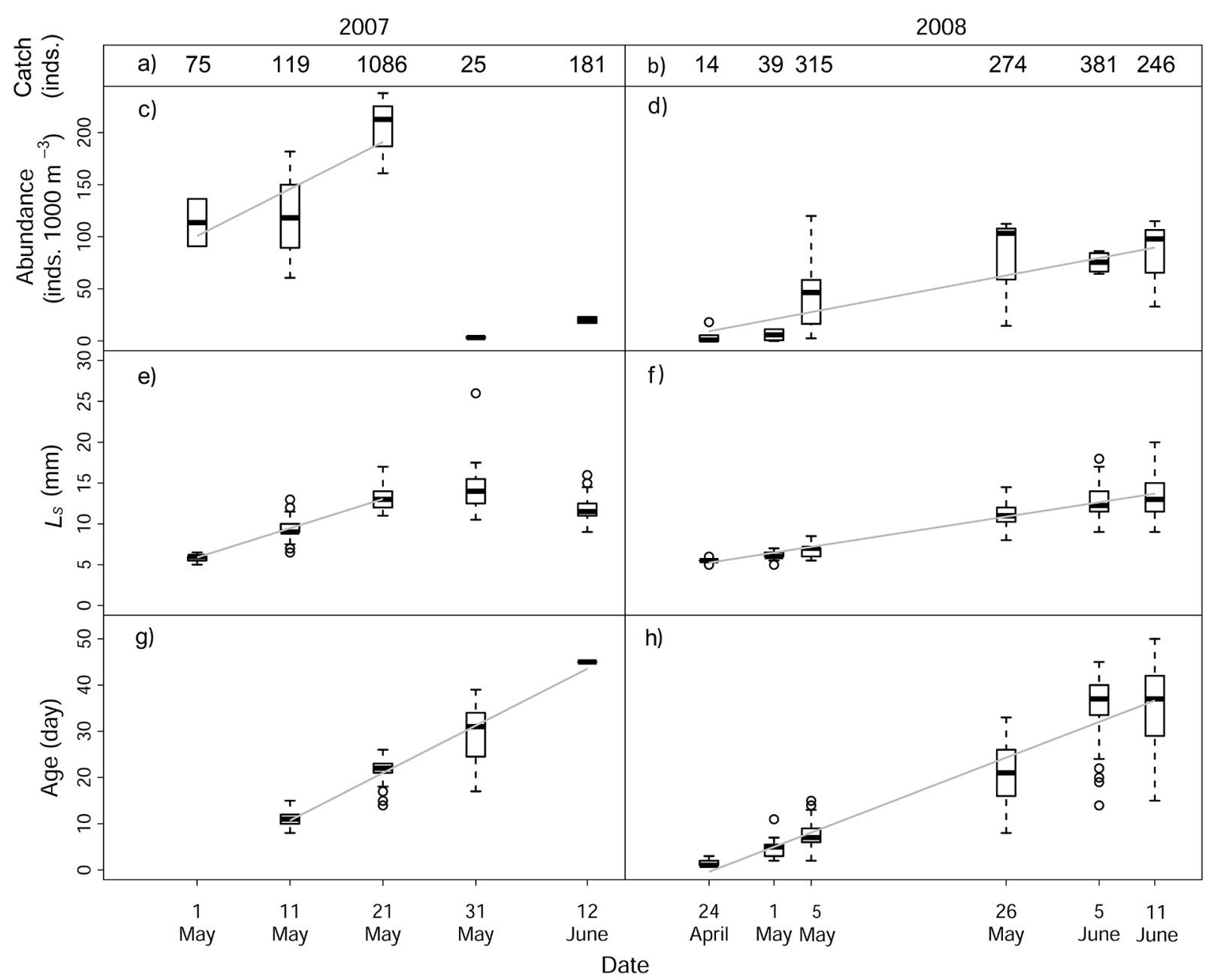

Fig. 2. Individual characteristics: (a), (b) catch, (c), (d) abundance, (e), (f) standard length ( $L_{\mathrm{S}}$ ), and (g), (h) age, of 0+ Sander lucioperca trawl catches in the Ř́mov Reservoir in (a), (c), (e), (g) 2007 and (b), (d), (f), (h) 2008. Grey lines indicate linear relationship between observed values and sampling time. Median values (thick lines), upper and lower quartiles (boxes), maximum and minimum values (whiskers), and outliers (dots) are shown.

\subsection{Environmental data}

Water temperature $\left({ }^{\circ} \mathrm{C}\right.$, at $1 \mathrm{~m}$ depth) and water level ( $\mathrm{m}$ above the Baltic sea level) were measured every day at 0700 hours from the sampling tower located $80 \mathrm{~m}$ from the dam by the Vltava River Authority. Zooplankton were sampled during the daytime at 3 week intervals (25 April, 16 May and 6 June in 2007 and 23 April, 14 May and 4 June in 2008) by vertical hauls from the bottom to the surface with a $200 \mu \mathrm{m}$ Apstein plankton net from a boat at the deepest part of the reservoir located $250 \mathrm{~m}$ from the dam. This was part of longterm monitoring programme of the reservoir. The samples were anaesthetised using chloroform and sorted into Copepoda and Cladocera (adults and copepodites). The zooplankton abundance was expressed as individuals per $0.01 \mathrm{~m}^{2}$.

\subsection{Data analyses}

The $S$. lucioperca catch was expressed as individuals captured per $1000 \mathrm{~m}^{3}$ of water sampled. The trends in $0+S$. lucioperca abundance, size, age and growth were tested by linear regression, where for direct comparison, the 24 April was set as day 1 for both years (the first sampling day in 2008). The data in the text are expressed as mean \pm S.D. All statistical analyses were performed in R 3.4.2 (R Developement Core Team, 2018).

\section{Results}

The total $0+S$. lucioperca catch and sampled water volumes were 1486 individuals and $23,898 \mathrm{~m}^{3}$ in 2017 and 1269 individuals and $29,192 \mathrm{~m}^{3}$ in 2008 (Fig. 2a, b). The standardised $0+S$. lucioperca catch at similar times in both years was different (Fig. 2c, d). In 2007, the $0+S$. lucioperca catch was $113.63 \pm 32.14$ individuals $1000 \mathrm{~m}^{-3}$ on 1 May and increased up to $203.87 \pm 39.19$ individuals $1000 \mathrm{~m}^{-3}$ on 21 May, followed by sudden drop by two orders on 31 May and stayed low until the end of the study period (Fig. 2c). In 2008, the $0+S$. lucioperca catch was low $4.24 \pm 7.15$ individuals $1000 \mathrm{~m}^{-3}$ on 24 April and the average catch increased gradually by $c$. 1.68 individuals day $^{-1}$ (slope of linear regression, $P<0.01$ ) during the study period to $82.00 \pm 43.28$ individuals $1000 \mathrm{~m}^{-3}$ on 11 June (Fig. 2d). 
In 2007, the growth of $0+S$. lucioperca was linear from 1 May $5.88 \pm 0.39 \mathrm{~mm} L_{\mathrm{S}}$ to 21 May $13.04 \pm 1.36 \mathrm{~mm}$ $L_{\mathrm{S}}(y=0.36 x+3.02, P<0.01)$ followed by the occurrence of $0+S$. lucioperca of similar or smaller size (Fig. 2e). In 2008, the $0+$ year growth was continuous during the whole study period from $5.61 \pm 0.17$ to $13.73 \pm 2.44 \mathrm{~mm} L_{\mathrm{S}}$ $(y=0.18 x+5.02 ; P<0.01$, Fig. 2f).

Sagittae otoliths were extracted and age determined from $0+S$. lucioperca from all sampling campaigns with the exception of 1 May 2007. The total number of read sagittae otoliths was 316 and 799 in 2007 and 2008. The range of $S$. lucioperca ages in 2007 was from $11.24 \pm 1.31$ days on 11 May to 45 days (only one individual) on 12 June (Fig. $2 \mathrm{~g}$ ) and in 2008 from $1.43 \pm 0.86$ days on 24 April to $35.56 \pm 7.65$ days on 11 July (Fig. 2h). The linear regressions between $S$. lucioperca age and the sampling dates were very significant: $y=1.05 x-$ 8.26; $P<0.01$ in 2007 and $y=0.76 x-0.77, P<0.01$ in 2008 (Fig. $2 \mathrm{~g}, \mathrm{~h}$ ). The S.D. of $0+S$. lucioperca age was not dependent on the sampling day in $2007(P>0.05)$, but significantly increased with the date of sampling in 2008 $(y=0.13 x+1.05, P<0.05)$.

The relationship between $0+S$. lucioperca $L_{\mathrm{S}}$ at given age in 2007 was divided into two parts. By 21 May, the growth was faster in the first $(y=0.45 x+4.62 ; P<0.01)$ than during the second part $(y=0.32 x+5.04, P<0.01$; Fig. 3a). In 2008, the relationship was the same during the whole study period $(y=0.26 x+5.09, P<0.01$; Fig. 3b).

In both years temperature increased during the study period (Fig. 4a). The spring was warmer in 2007 compared to 2008 when a more rapid temperature increase was observed (slopes of linear regressions 0.18 and 0.24 in 2007 and 2008). The water level was on average $1.37 \mathrm{~m}$ higher in 2008 compared to 2007 and stable in the study period (Fig. 4a). During the study periods, the abundance of Cladocera and Copepoda decreased in 2007 compared to increased abundance of Cladocera and peaking abundance of Copepoda in the middle of May in 2008 (Fig. 4b).

\section{Discussion}

The development of a cohort is a complex process affected by many factors acting at different times (Jakobsen et al., 2009). The identification of the exact timing of a cohort bottleneck including changes in environmental variables is rare (Jůza et al., 2014). The present study was fortunate in the timing of sampling in two consecutive years with significantly different development of $0+S$. lucioperca cohorts.

The greatest volume and depth of deep reservoirs is the lacustrine zone close to the dams. During the early larval and juvenile period $S$. lucioperca occur in the pelagic zone (Frankiewicz et al., 1996; Specziár, 2005), that can be quantitatively sampled by trawling (Jůza and Kubečka, 2007; Jůza et al., 2010). During the night, $0+S$. lucioperca occur mainly in layers close to the surface (Čech et al., 2005), but in the day some fish can migrate into deep layers (Cech et al., 2007; Jůza et al., 2015). In this study, the pelagic layer was sampled during the day on 12 June in 2007 and 26 May in 2008. Therefore the reported catches at these two times should be interpreted as minimal. The littoral zone represents a minor part of deep reservoirs, and due to water level fluctuations the

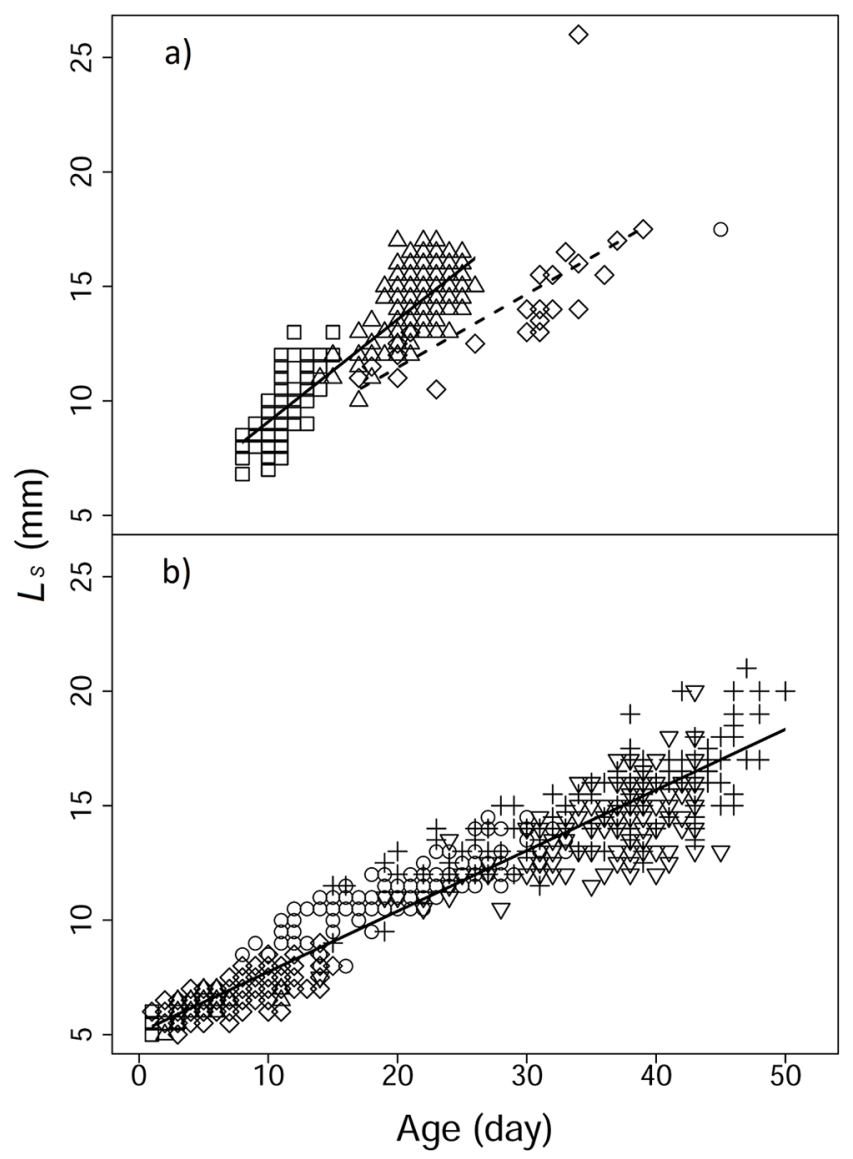

Fig. 3. Relationships between Sander lucioperca standard length $\left(L_{\mathrm{S}}\right)$ at age in (a) 2007 (square 11 May, triangle 21May, rhombus 31 May and circle 12 June) and (b) 2008 (square 24 April, triangle 1 May, rhombus 5 May, circle 26 May, inverted triangle 5 June and cross 11 June). Black lines indicate linear relationship between $L_{\mathrm{S}}$ and age. The sampling period in 2007 is divided into two parts, to 21 May and later. In the second part, the largest $0+S$. lucioperca (outlier) was omitted from the regression.

macrophyte dominated littoral is usually poorly developed and the pelagic zone begins close to the shore (Krolová et al., 2012).

In both years, the sampling began at the time of $S$. lucioperca hatching and their occurrence in the pelagic zone. Despite the fact that data on the parental stock were not collected, a previous study indicated that adult densities were low. Poaching was suggested to be the main reason for low abundance of $S$. lucioperca populations, even in drinking water storage reservoirs (such as the Rímov Reservoir) where all public entry is officially prohibited (Vašek et al., 2013). Similarly, predator pressure was not the reason for the sudden drop of the $S$. lucioperca cohort in 2007. The main predator of larvae and juvenile fish was the European perch Perca fluviatilis L., 1758 (Dörner et al., 1999). They prefer benthic habitats and their abundance in the Rímov Reservoir is low (Prchalová et al., 2009; Ríha et al., 2009).

The main influence on the $0+$ cohorts' development is temperature as it affects other processes (e.g. stratification and growth of poikilothermic organisms) in a waterbody. The optimal temperature for $S$. lucioperca growth is relatively high, 


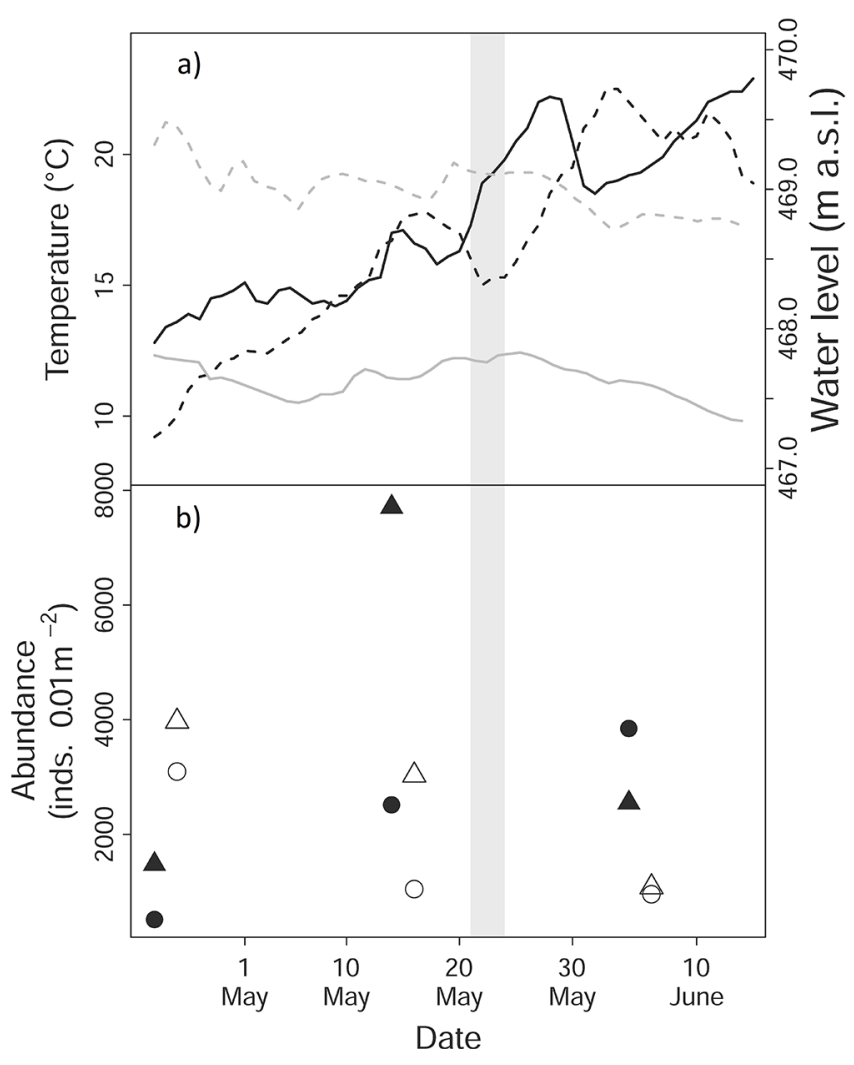

Fig. 4. (a) Temperature (continuous black line in 2007 and dashed in 2008), and water level (continuous grey line in 2007 and dashed in 2008) and (b) abundance of Cladocera (circles) and Copepoda (triangles) in 2007 (empty symbols) and 2008 (black symbols) during the $0+$ Sander lucioperca sampling period. The grey bar indicates the period of $0+S$. lucioperca cohort collapse in 2007.

28-30 ${ }^{\circ} \mathrm{C}$ (Hokanson, 1977; Wang et al., 2009) and many previous studies reported a positive relationship between $S$. lucioperca cohort strength and temperature (Lehtonen et al., 1996; Kjellman et al., 2003; Heikinheimo et al., 2014). The spring temperature increase stimulates $S$. lucioperca to spawn and a higher temperature reduces the time to hatching (Lappalainen et al., 2003; Löffler et al., 2008). The warm spring in 2007 stimulated $S$. lucioperca to spawn, shortened the time before hatching and therefore many fish occurred at a similar time in the reservoir. The short time for development at the egg stage results in smaller larvae which have higher mortality (Löffler et al., 2008). The $0+S$. lucioperca catch gradually increased in 2007 only until the middle of May. In 2008 , the warming was slower and the $0+S$. lucioperca abundance increased during the whole study period suggesting prolonged hatching.

The $0+S$. lucioperca showed their fastest growth during the first period in 2007 and the slowest in 2008. The fastest growth corresponds to the observation of growth of $0.45 \mathrm{~mm}$ day $^{-1}$ in a shallow pond with high $0+S$. lucioperca density and the artificial addition of zooplankton (Peterka et al., 2003). In ponds with lower $0+S$. lucioperca densities, the growth was $1.05-0.90 \mathrm{~mm} \mathrm{day}^{-1}$ (Peterka et al., 2003). The same authors reported $0+S$. lucioperca growth in 1993 in the reservoir to be only $0.19 \mathrm{~mm} \mathrm{day}^{-1}$, but they commented that the observation was an artefact due to the prolonged spawning period in the reservoir (Peterka et al., 2003). The observation in 2008 supports this explanation because of similar growth $\left(0.18 \mathrm{~mm} \mathrm{day}^{-1}\right)$ and age determination. A more reliable growth rate of $0.23 \mathrm{~mm}$ day $^{-1}$ was provided by Ljunggren (2002) from cultured S. lucioperca in Sweden, a value close to the $0.26 \mathrm{~mm}$ day $^{-1}$ calculated for $L_{\mathrm{S}}$ at the age in our study in 2008. In a laboratory experiment, Löffler et al. (2008) demonstrated temperature dependent growth (mean 13.0 \pm 1.1 and $21.8 \pm 2.1 \mathrm{~mm}$ total length at 15.5 and $18.0^{\circ} \mathrm{C}$ after 40 days).

Sander lucioperca larvae switch to exogenous feeding at 5-6 $\mathrm{mm} L_{\mathrm{S}}$ at an age of 8 days (Peterka et al., 2003; Löffler et al., 2008). High zooplankton abundance $\left(>585\right.$ prey $\left.1^{-1}\right)$ should be present at the time of the switch and later on can be lower (Ljunggren, 2002). The first food are Copepoda followed by Cladocera (Peterka et al., 2003; Specziár, 2005; Kratochvíl et al., 2010). The zooplankton data collected during the spring in 3 weeks, at the time of fast changes in the zooplankton community (Sommer et al., 2012), were insufficient for development of a predictive model. Although the whole water column was sampled, approximately $90 \%$ of the crustacean zooplankton in the Rímov Reservoir is concentrated in the epilimnetic layer without any vertical diurnal migration (Sed'a 1989, Sed'a et al., 2007) and therefore the zooplankton density data can suggest the processes driving $0+S$. lucioperca cohorts.

The first fast growing $0+S$. lucioperca group in 2007 matched the time of high zooplankton abundance, but later on, the cohort suddenly collapsed at the time of rapid temperature increase. After this period, only slower growing individuals were captured and at the same time the zooplankton abundance decreased. The mismatch in timing of the high zooplanktonabundance period is similar to one described by Persson and Brönmark (2008) in the Swedish Lake Ringsjön and by Wysujack et al. (2002) in the German Lake Feldberger Haussee. In the Rímov Reservoir fish migration to the littoral zone is highly improbable because the zone occupies only a limited part of the reservoir (Blabolil et al., 2016) and migration to deeper layers is mainly conducted during the day (Jůza et al., 2010). Previous studies demonstrated no statistical significant size selectivity (Jůza et al., 2010, 2012) with $S$. lucioperca catches of up to $40 \mathrm{~mm} L_{\mathrm{S}}$ (Čech et al., 2007). Therefore although the present study is based on only the uppermost pelagic layer, it reflects the representative part of $0+S$. lucioperca cohorts. The possibility that some fast growing (usually piscivorous, independent of zooplankton density) S. lucioperca could escape sampling, however, could not be excluded as the largest individuals were not captured and it is very rare that the largest individuals suffer the highest mortality during early ontogeny.

The $0+S$. lucioperca catch increased in 2008 and the growth was continuous suggesting gradual supplement of newly hatched fish, resulting in a higher $0+S$. lucioperca catch at the end of the study period. Moreover, in the three zooplankton samples of the 2008 period the abundance of Cladocera increased and the abundance of Copepoda peaked during the first half of May. Therefore a significant part of $S$. lucioperca larvae abundance matched the most suitable period of switching between food sources in 2008.

Water level should be considered when comparing cohort development. Water level in 2008 was more than $1 \mathrm{~m}$ higher than in 2007 . When the water level is high, adult phytophilous 
S. lucioperca have more suitable habitats with flooded terrestrial vegetation for their nests (Dimitrieva, 1973). There is a chance that the availability of suitable substrata stimulates more fish to spawn than when water levels are low.

This study focused on $0+S$. lucioperca cohorts. The collapse in 2007 might be one of the results of intraspecific competition. In the Rímov Reservoir, $0+S$. lucioperca (5-10\% of catch $0+$ fishes) is usually present with ruffe Gymnocephalus cernua (L., 1758) (0-5\%) and much more abundant $0+P$. fluviatilis (90-95\%) in May followed by $0+$ fish density increase by newly hatched cyprinids represented by the main species in the reservoir bream Abramis brama (L., 1758), bleak Alburnus alburnus (L., 1758) and roach Rutilus rutilus (L., 1758) in June, when cyprinids dominate (>90\%) in the pelagic community (Jůza et al., 2010, 2014). All these species can compete with $0+S$. lucioperca for food sources.

The sampling interval could be more frequent than $c$. 10 days that we carried out to better capture the timing of cohort collapse or development. The data series in 2008 is not complete because the samples taken in 15 May were spoiled by incorrect storage. The study period of $c$. 50 days seemed to be sufficient. A previous study (Blabolil et al., 2016) dealing with $0+S$. lucioperca cohorts at the end of summer, found the cohort in 2008 to be much stronger than in 2007 and therefore supporting our observation.

Intensive sampling can reveal short term fatal periods in development of a $0+S$. lucioperca cohort. Quantitative sampling in the pelagic zone can provide robust abundance estimates and captured fish can be used for other analyses. Daily estimates of age can provide valuable insights into fish growth. Routine monitoring of environmental parameters performed by water authorities may provide useful background data for interpretation of scientific observations. In this study, the cohorts were clearly determined early after hatching. The results provide valuable insights that can guide further research, help fisheries managers and broaden knowledge on $S$. lucioperca early life history.

Acknowledgments. Thanks are given to J. Frouzová, Z. Prachař and K. Soukalová for assistance in the field and laboratory work, to M. Sed'a and J. Zemanová for processing the zooplankton samples, to John Craig for editing the English and to the Vltava River Authority for enabling the fieldwork and providing temperature and water level data. This study was supported by the project QK1920011 Methodology of predatory fish quantification in drinking-water reservoirs to optimize the management of aquatic ecosystems.

\section{References}

Balon EK. 1975. Reproductive guilds of fishes: A proposal and definition. J Fish Res Board Can 32: 821-864.

Blabolil P, Frouzová J, Matěna J, Peterka J. 2018. Immersion mass marking of pikeperch (Sander lucioperca) larvae in oxytetracycline hydrochloride and its detection using fluorescence microscopy. Biologia 73: 531-535.

Blabolil P, Ricard D, Peterka J, et al. 2016. Predicting asp and pikeperch recruitment in a riverine reservoir. Fish Res 173: 45-52.

Bone Q, Moore R. 2008. Biology of Fishes, 3rd edn. New York: Routledge, $496 \mathrm{p}$.
Campana S. 2001. Accuracy, precision and quality control in age determination, including a review of the use and abuse of age validation methods. J Fish Biol 59: 197-242.

Čech M, Kratochvíl M, Kubečka J, Draštík V, Matěna J. 2005. Diel vertical migrations of bathypelagic perch fry. J Fish Biol 66: 685702.

Čech M, Kubečka J, Frouzová J, Draštík V, Kratochvíl M, Jarošík J. 2007. Impact of flood on distribution of bathypelagic perch fry layer along the longitudinal profile of large canyon-shaped reservoir. J Fish Biol 70: 1109-1119.

Čech M, Vejř́ik L, Peterka J, et al. 2012. The use of artificial spawning substrates in order to understand the factors influencing the spawning site selection, depth of egg strands deposition and hatching time of perch (Perca fluviatilis L.). J Limnol 71: 18.

CEN. 2005. Water quality - Sampling of fish with multi-mesh gillnets. EN 14757.

CEN. 2014. Water quality - Guidance on the estimation of fish abundance with mobile hydroacoustic methods. EN 15910.

Cowx IG. 1994. Stocking strategies. Fish Manag Ecol 1: 15-30.

Dimitrieva EN. 1973. Spawning grounds of zander Lucioperca lucioperca L. and Volga zander Lucioperca volgensis (Gmelin) in the Ural River. Vopr Ikhtiol 14: 934-937.

Dörner H, Wagner A, Benndorf J. 1999. Predation by piscivorous fish on age-0 fish: spatial and temporal variability in a biomanipulated lake (Bautzen reservoir, Germany). Hydrobiologia 408/409: 39-46.

Eklöv P, Persson L. 1995. Species-specific antipredator capacities and prey refuges: interactions between piscivorous perch (Perca fluviatilis) and juvenile perch and roach (Rutilus rutilus). Behav Ecol Sociobiol 37: 169-178.

FAO. 2018. Fishery and aquaculture statistics. Global production by production source 1950-2016 (FishstatJ). Rome.

Frankiewicz P, Dabrowski K, Zalewski M. 1996. Mechanism of establishing bimodality in a size distribution of age-0 pikeperch, Stizostedion lucioperca (L.) in the Sulejow Reservoir, Central Poland. Ann Zool Fenn 33: 321-327.

Garvey JE, Stein RA. 1998. Competition between larval fishes in reservoirs: the role of relative timing of appearance. T Am Fish Soc 127: 1021-1039.

Heikinheimo O, Pekcan-Hekim Z, Raitaniemi J. 2014. Spawning stock-recruitment relationship in pikeperch Sander lucioperca (L.) in the Baltic Sea, with temperature as an environmental effect. Fish Res 155: 1-9.

Hokanson KEF. 1977. Temperature requirements of some percids and adaptations to the seasonal temperature cycle. J Fish Res Board Can 34: 1524-1550.

Hoxmeier RJH, Wahl DH, Brooks RC, Heidinger RC. 2006. Growth and survival of age-0 walleye (Sander vitreus): interactions among walleye size, prey availability, predation, and abiotic factors. Can J Fish Aquat Sci 63: 2173-2182.

Jakobsen T, Fogarty MJ, Megrey BA, Moksness E. 2009. Fish reproductive biology: Implications for assessment and management. John Wiley \& Sons Ltd. 488 p.

Jůza T, Čech M, Kubečka J, et al. 2012. The influence of the trawl mouth opening size and net colour on catch efficiency during sampling of early stages of perch (Perca fluviatilis) and pikeperch (Sander lucioperca) in the bathypelagic layer of a canyon-shaped reservoir. Fish Res 123-124: 21-25.

Jůza T, Čech M, Kubečka J, Vašek M, Peterka J, Matěna J. 2010. The influence of the trawl mouth opening size and net colour on catch efficiency during sampling of early fish stages. Fish Res 105: 125-133. 
Jůza T, Kubečka J. 2007. The efficiency of three fry trawls for sampling the freshwater pelagic fry community. Fish Res 85: 299-304.

Jůza T, Ricard D, Blabolil P, et al. 2015. Species-specific gradients of juvenile fish density and size in pelagic areas of temperate reservoirs. Hydrobiologia 762: 169-181.

Jůza T, Vašek M, Kratochvíl M, et al. 2014. Chaos and stability of age-0 fish assemblages in a temperate deep reservoir: unpredictable success and stable habitat use. Hydrobiologia 724: 217-234.

Kjellman J, Lappalainen J, Urho L, Hudd R. 2003. Early determination of perch and pikeperch recruitment in the northern Baltic Sea. Hydrobiologia 495: 181-191.

Kratochvíl M, Čech M, Vašek M, et al. 2015. Diel vertical migrations of age $0+$ percids in a shallow, well-mixed reservoir. J Limnol 69: 305-310.

Krolová M, Č́žková H, Hejzlar J. 2012. Depth limit of littoral vegetation in a storage reservoir: A case study of Lipno Reservoir (Czech Republic). Limnologica 42: 165-174.

Lappalainen J, Dörner H, Wysujack K. 2003. Reproduction biology of pikeperch (Sander lucioperca (L.) - a review. Ecol Freshw Fish 12: 95-106.

Lehtonen H, Hansson S, Winkler H. 1996. Biology and exploitation of pikeperch, Stizostedion lucioperca (L), in the Baltic Sea area. Ann Zool Fenn 33: 525-535.

Ljunggren L. 2002. Growth response of pikeperch larvae in relation to body size and zooplankton abundance. J Fish Biol 60: 405-414.

Löffler J, Ott A, Ahnelt H, Keckeis H. 2008. Early development of the skull of Sander lucioperca (L.) (Teleostei: Percidae) relating to growth and mortality. J Fish Biol 72: 233-258.

Moberg GP, Mench JA. 2000. The biology of animal stress, basic principles and implications for animal Welfare. Oxon, UK: CABI Publishing, $384 \mathrm{p}$.

Morgan MJ. 2008. Integrating reproductive biology into scientific advice for fisheries management. J Northwest Atl Fish Sci 41: $37-51$.

Pepin P. 1991. Effect of Temperature and size on development, mortality, and survival rates of the pelagic early life history stages of marine fish. Can J Fish Aquat Sci 48: 503-518.

Persson A, Brönmark C. 2008. Pikeperch Sander lucioperca trapped between niches: foraging performance and prey selection in a piscivore on a planktivore diet. J Fish Biol 73: 793-808.

Peterka J, Matěna J, Lipka J. 2003. The diet and growth of larval and juvenile pikeperch (Stizostedion lucioperca (L.): a comparative study of fishponds and a reservoir. Aquacult Int 11: 337-348.
Prchalová M, Kubečka J, Čech M, et al. 2009. The effect of depth, distance from dam and habitat on spatial distribution of fish in an artificial reservoir. Ecol Freshw Fish 18: 247-260.

R Developement Core team. 2018. R: A language and environment for statistical computing. R foundation for statistical computing.

Ralston S, Williams AH. 1988. Numerical integration of daily growth increments: an efficient means of aging tropical fishes for stock assessment. Fish Bull 87: 1-16.

Rao TR. 2003. Ecological and ethological perspectives in larval fish feeding. J Appl Aquacult 13: 145-178.

Ríha M, Kubečka J, Vašek M, et al. 2009. Long-term development of fish populations in the Rímov Reservoir. Fish Manag Ecol 16: $121-129$

Sed'a J. 1989. Main factors affecting spring development of herbivorous cladocera in the Rímov Reservoir (Czechoslovakia). Ergebnisse Limnol 6: 619-630.

Sed'a J, Devetter M. 2000. Zooplankton community structure along a trophic gradient in a canyon-shaped dam reservoir. J Plankton Res 22: $1829-1840$.

Sed’a J, Petrusek A, Macháček J, Šmilauer P. 2007. Spatial distribution of the Daphnia longispina species complex and other planktonic crustaceans in the heterogeneous environment of canyon-shaped reservoirs. J Plankton Res 29: 619-628.

Sommer U, Adrian R, De Senerpont Domis L, et al. 2012. Beyond the plankton ecology group (PEG) model: Mechanisms driving plankton succession. Annu Rev Ecol Evol Syst 43: 429-448.

Specziár A. 2005. First year ontogenetic diet patterns in two coexisting Sander species, $S$. lucioperca and $S$. volgensis in Lake Balaton. Hydrobiologia 549: 115-130.

Specziár A, Turcsányi B. 2017. Management of pikeperch stocking in Lake Balaton: effect of season, area, fish size and method of release on the rate and distribution of recaptures. Knowl Manag Aquat Ecosyst 418: 52.

Vašek M, Prchalová M, Peterka J, et al. 2013. The utility of predatory fish in biomanipulation of deep reservoirs. Ecol Eng 52: 104-111.

Wang N, Xu X, Kestemont P. 2009. Effect of temperature and feeding frequency on growth performances, feed efficiency and body composition of pikeperch juveniles (Sander lucioperca). Aquaculture 289: 70-73.

Wood CM, McDonald DG. 1997. Global warming: Implications for freshwater and marine fish. Cambridge: Cambridge University Press, $444 \mathrm{p}$.

Wysujack K, Kasprzak P, Laude U, Mehner T. 2002. Management of a pikeperch stock in a long-term biomanipulated stratified lake: efficient predation vs. low recruitment. Hydrobiologia 479: 169-180.

Cite this article as: Blabolil P, Čech M, Jůza T, Peterka J. 2019. Variability of pikeperch Sander lucioperca (L. 1758) cohorts in early life history. Knowl. Manag. Aquat. Ecosyst., 420, 43. 